\title{
Perceived Sustainability Practices, Turnover Intentions, and Organizational Identification in Hotel Industries
}

DOI: 10.7595/management.fon.2019.0009

\begin{abstract}
:
Research Question: The present study intends to study the effect of employees' perception of their hotel's sustainability practices and motive to undertake those practices on their identification with the organization and their intentions to quit. Motivation: Over the past few years, the hotel industry has heeded to the need of sustainability, but its effect on human resource outcomes needs attention. Earlier research reports that adopting sustainable practices enhances the reputation of the organisations, and positively impacts the employees' organisational identification and intention to stay in the organisation. The bearings of such practices are seen in the expected cash flows and growth of the industry. Idea: The core idea behind this research was to investigate the effect of perceived sustainability activities and motive attribution on human resource outcomes. In the study, perceived sustainability activities and motive attribution were the independent variables whose effect was seen in the human resource outcomes, namely, organizational identification and intentions to quit. Data: The sample comprises 137 managers from star hotels of Vadodara and Ahmedabad. The data were collected over a period of 4 months. Tools: The survey questionnaire adopted already established scales on environmental sustainability, turnover intentions, organisational identification and motive attribution. The researchers added a few questions on social and economic sustainability to capture the whole concept of sustainable development. Findings: The findings of the study indicate employee welfare is a significant predictor of organizational identification and turnover intentions in hotel industries. Moreover, intrinsic, as well as extrinsic motive attribution are necessary to encourage employees to take ownership and retain it. Contribution: The study implies that hoteliers must channelize their resources to enhance employee welfare. Utmost care and support will be reciprocated in terms of higher organisational identification and lower turnover rates. Efforts must also be made to educate all the employees as regards the reasons for undertaking policies and actions. This will help them understand the organisational values and encourage them to align their values with the organisation. The way employees allocate reasons for conducting sustainability has implications for the judgement and actions of both managers and employees. It also plays a role in motivating them to involve themselves in sustainable activities. This research also suggests research areas for future studies. The researchers foresee the results of this research will be intriguing for policy makers and future researchers as knowledge of how employees inculcate sustainability in their actions proves the policy success rate.
\end{abstract}

Key words: Sustainability practices, turnover intention, organizational identification, motive attribution

JEL classification: Q01

\section{Introduction}

The hospitality industry is a servicing business contributing significantly to the economic growth of the country. The foundation of the hospitality sector is built upon three major segments - food and beverages, accommodation and travel and tourism. The hospitality and tourism industry are the fastest growing segments, revenue-wise and employment wise. They contribute 6.23 percent to the National GDP and 8.78 percent of the total employment in India. India is ranked third among 184 countries in terms of travel \& tourism's total contribution to GDP in 2016. As per the World Travel \& Tourism Council (WTTC) report, in 
2016 Travel \& Tourism directly supported $25,394,500$ jobs (5.8\% of total employment). This number is expected to rise to $31,910,000$ jobs (6.1\% of total employment) in 2027 (World Travel \& Tourism Council, 2016).

The hotel industry is based on the ideology of customer service and follows the philosophy of "customer first". It aims at achieving effectiveness and satisfied customers through trained and skilled employees. However, due to the lack of professional training and skill development in the existing workforce in hotel industry, the industry is striving to sustain against employee turnover. Employee turnover is the rotation of workers around the labour market; the number of workers who leave the organisations are replaced by new employees (Abbasi \& Hollman, 2000). According to Woods (2009), a high turnover rate means that existing employees are leaving the organization frequently and are being replaced by novice employees, which can have detrimental effects on the company performance and efficiency. The turnover intention, which is a good predictor of actual turnover, can be defined as the intention of a worker to leave the organization within a given period. The actual turnover increases as the intentions to leave the organization become stronger. A meta-analytic study conducted by Steel and Ovalle (1984) revealed that the intention to leave and employee turnover were significantly correlated, and the intention was a better predictor of turnover than job satisfaction, nature of the work and commitment. It is necessary that the industry should address the problem because it requires skilled and experienced manpower to ensure long term customer retention and loyalty towards their brand. Park and Shaw (2012) conducted a meta-analysis which validated the proposition that high turnover rates can substantially reduce the organization performance. It implies negative impact on the workforce as well as the financial performance. Thus, organizations must strategize to minimise turnover rates to tackle the workforce and financial risks.

One of the major challenges faced by the Indian hospitality sector is a high turnover rate. The employee morale and service quality to the hotel guests are adversely affected by excessive turnover as it created difficulties in recruitment, and enhances training expenses. According to an article in The Hindu, the attrition rate as found in the year 2011 was about $25-30 \%$ - across different levels. This led to an increase in the employee cost by an average of 20 per cent (Ravikumar, 2011)

\subsection{Conceptual Framework}

The high attrition rate can be attributed to the job dissatisfaction of employees. Plausibly, this problem arises due to laborious working hours and low pay scale. The hotel industry thrives on the satisfaction of the customer base of the organization. The hospitality sector must realize that the satisfactory service will be provided by satisfied employees. If the employees are not satisfied, they will not be motivated to deliver a quality service to the customers. If this problem is not dealt with, the industry will find itself investing large amounts in recruiting, training new employees at regular intervals (Mukherjee \& Malhotra, 2004; Yee, Yeung \&Cheng, 2008).

1.1.1 Organizational Identification and intent to leave: How can hotels reduce turnover of employees? The social exchange theory (Blau, 1964) propagates that perceived organizational care is reciprocated by developing a sense of identification that obligates employees to stay with the organization (Jones, 2010) and make contributions to the organizations (Aselage \& Eisenberger, 2003). Organizational identification refers to "the perception of oneness with or belongingness to an organization, where the individuals define him or herself in terms of the organization(s) which he/ she is a member" (Mael \& Ashforth, 1992, p. 104). This perception of oneness fosters behaviours congruent to the organization's goals and values. The organization's support and efforts to improve employee work-life quality induces a sense of identification and commitment which leads to high employee performance. Further, research suggests that an individual's need for uniqueness generates loyalty towards organizations categorised as distinct (Brewer, 1991; Mael \& Ashforth, 1989). One of the ways organizations may stand out and be distinct is by adopting sustainable practices following a global standard. Thus, an organization which is perceived as an organization with sustainable practices may have more loyal employees as compared to their counterparts. The research in the area of organizational prestige and reputation suggest that, if employees believe that outsiders see the organization positively, they willingly want to identify with the organization and develop favourable performance such as citizenship behaviour and intra-organizational cooperation (Dutton, Duckerich \& Harquail, 1994), whereas, when employees think that the organization is negatively perceived by outsiders they might want to disassociate themselves from it. Previous research reported that organization reputation is imperative in developing self-esteem and awareness of group membership, loyalty (Dutton et al., 1994; Carmeli, Gilat, \& Waldman 2007; Kim \& Kim, 2016). A contemporary study by Riketta (2005) has emphasized the benefits of identification in the workplace. According to this meta-analysis, organizational identification has been found 
to correlate with intent to leave and with organizational prestige The reputation of the organization (Mael \& Ashforth, 1989) and organizational policies (Cheney, 1983) foster organizational identification amongst employees. The organization's decision to engage in sustainable practices has implications for its success and the stakeholder's judgement. This in turn impacts employees' intentions to stay.

1.1.2 Sustainable Development Practices and Hotel Industries: With the publication of 'Our Common Future", otherwise known as Brutland's report, by World Commission on Environment and Development in 1987, sustainable development made inroads to the management strategies and policies in different sectors. This report addressed the issues concerning long-term environmental, social and economic issues and exerting efforts required to successfully deal with it. Bruntland defines sustainable development as "development that meets the needs of the present without compromising the ability of future generations to meet their own needs." (pp. 37, 1987). Sustainable development is about achieving environmental, economic, and social welfare for the present as well as the future generations (Azapagic \& Perdan, 2000). Hotels have learned the impacts of engaging in sustainable practices on the firm's financial performance (Ameer \& Othman, 2011; Dembo, 2017). With increasing awareness, the demand of sustainable hotel operations by hotel industries is expanding. Hotels that engage in sustainable activities reduce their costs of survival. Sustainable practices appear altruistic to customers, creating a positive image of the hotel (UK Essays, 2013). Although investments in sustainable practices may not be beneficial in the short-term payback, sustainable practices contribute to great savings in the long-run. This also ensures additional revenue through cost-saving measures, enhanced brand image, positive guest experience and employee retention which in turn warrants the hotel's ability to stay in the market for a longer term (Goldstein, 2012).

1.1.3 Perceived sustainable practices and motive attribution: The top and middle management level employees are involved in aligning the strategies and practices of the organization with the vision, as well as the mission of the organization, thus having access to all background motives and purposes. The managerial level employees have more information about the intentions behind organizational actions than the external stakeholders. Employees make judgements about the organization's policies, decisions and strategies which guide their work place behaviour and performance (McMurray, Pirola-Merlo, Sarros, \& Islam, 2010; Permarupan, Saufi, Kasim, \& Balakrishnan, 2013). These judgements can be understood to be framed on the basis of their understanding of organization's motives to engage in sustainable practices. The motive attribution has been studied as intrinsic and extrinsic motives (Vlachos, Panagopoulos \& Rapp, 2013). Intrinsic sustainable practices are sincere efforts of organizations to contribute to the sustainable development (Lee \& Seo, 2017). When employees judge the organisation's practices as positive, it reinforces identification; furthermore, it results in active engagement in the sustainable activities (as cited in Froese, 2013). Employee engagement and identification is more related to intrinsic motive attribution, rather than perception of the practices as an effort for brand building and image management. Sustainable organizations create a reputation for being distinct from other organizations. Extrinsic practices are those strategic plans meant to achieve a specific purpose. Such practices are predominantly guided by the motivation of attracting stakeholders, improving the brand image and avoiding punishment from society (Story \& Neves, 2015). Studying the contribution of motive attribution to the employees' organizational identification and turnover intention may help organizations to create a right kind of perception in the employees to influence their workplace behaviour.

The research done in the hotel industry in the South and South-east Asia in the last decade has focused on employee turnover and retention strategies. However, in spite of creative and innovative techniques to retain the employees, the turnover rate remains high. A study of Taiwan hotel workers reported that $80 \%$ turnover, with $70 \%$ of them being given recruitment propositions, where the authors suggest managerial effort to understand the individual needs and expectations (Yang, Wan \& Fu, 2012). A large study $(n=884)$ carried out on pan Indian luxury hotels (Mohsin, Lengler, \& Kumar, 2013) suggest the effect of antecedents like organizational enthusiasm, and stimulating job conditions, job security and organizational loyalty on turnover intention. The results of the study supported the notion that the employees' organisational loyalty has a negative effect on his/her intention to leave. The study findings contradicted earlier findings suggesting the employees' intention to resign from the job being increased with job security and earnings. The study suggested implications for managers of luxury hotels that too much of a good thing may not be an assurance that employees will remain in the job (Mohsin, Lengler, \& Aguzzoli, 2015). Another study in Cyprus on employees of hotel industries report a negative relationship between affective organizational commitment, extrinsic job satisfaction and turnover intention. However, a negative association between intrinsic job satisfaction and turnover intention was not supported (Zopiatis, Constanti, \& Theocharous, 2014). Most of the studies conducted in hotel and hospitality industry have used organizational commitment, loyalty, involvement to explain employee turnover intention. However, these studies together support the fact that organizational commitment, motivation and loyalty are not enough to explain employees' intention to leave the job. We need to further understand the process behind it. Secondly, most of the research cited here and 
other existing research carried out in hotel industries, mostly target employees, and not managers. Thirdly, when the effect of perceived sustainability practices are being extensively studied on organizational performance in various sectors/industries (i.e.,, and Yu, 2014); very few research works have attempted to study the effect of perceived sustainability practices on employees' commitment, identification and loyalty as well as on intent to leave in the hotel industry.

On the back drop of the above-mentioned findings, the following hypotheses were conjectured $\mathrm{H}_{1}$ : There will be a significant positive effect of perceived sustainable practices on organizational identification of employees

$\mathrm{H}_{2}$ : There will be a significant negative effect of perceived sustainable practices on turnover intention $\mathrm{H}_{3}$ : There will be a significant effect of motive attribution on organizational identification of employees.

$\mathrm{H}_{4}$ : There will be a significant effect of motive attribution on intent to leave.

\section{Method}

\subsection{Sample}

Participants in this study were 137 first-line, middle, and senior managers from star hotels of Vadodara and Ahmedabad, two major cities of Gujarat, a western state of India. Most of the hotels are part of pan India hotel chains and thus the managers here are from different states, representing the diversity of Indian culture. The sample comprised 122 male and 15 female participants from Vadodara and Ahmedabad. Their experience in current organisation varied between 1 to over 10 years. On an average, these managers work for more than 8 hours a day. There were $78 \%$ of the managers that were locals, while $22 \%$ were transferred or moved to these cities for job opportunities. The research used a correlational design with a survey research method.

The data was collected from November to February, which is the tourist season in Gujarat, and thus it affected the random selection of the sample. The managers who were willing to participate in the study and could finally afford time to participate in the study comprised the final sample for the research.

\subsection{Procedure}

The HR managers and/or general managers were approached for permission. After seeking permission, if the managers were available, the questionnaires were distributed to the employees and data were collected. The respondents did not report any difficulties while answering the questionnaire as it was converted in Hindi language. More than 50 hotels of Vadodara and Ahmedabad were approached for the permission, however, only 43 hotels gave permission to conduct the survey or returned the filled questionnaires. The data collection was conducted over a period of 4 months between November and February, which is the tourist season in Gujarat, and thus it affected the random selection of the sample. The managers who were willing to participate in the study and could finally afford time to participate in the study comprised the final sample for the research. Collecting data from managers was very difficult because of the work overload and, to some extent, unstable workforce in the hotel industry. The overall response rate was $75 \%$. It was observed that many managers to whom the questionnaires were handed over left their jobs during the data collection. After the data collection process, the data were analysed using SPSS (version 23). To draw inferences from the data, the researchers used regression analysis to see the effect of perceived sustainability practices and motive attribution on the two outcome variables.

\subsection{Measures}

The questionnaire administered to the participants consisted of the following sections Personal Data Sheet: where the participants gave information about age, gender, current experiences, permanent residency, working hours and star accreditation of the hotel the respondent worked in and the ownership of the hotel.

Organizational Identification: items were adopted from Mael \& Ashforth's (1992) six-item scale.

Turnover Intention: the items were adopted from Giffen (2015) who used a Roodt's 6-item scale. A five-point Likert scale was used to measure the intention of employees to quit the organization from "never" to "always". The items on intent to leave were positively keyed, while the items on job satisfaction were negatively keyed. A high score on this scale would suggest that the individual has high intentions to leave the current organization and poor job satisfaction. 
Sustainable practices: the scale included items adopted from Sivika Saenyanupap's (2005) work on environmental sustainability practices. This scale was further strengthened by adding relevant items which could measure the sustainability practices not only in terms of environmental sustainability, but social and economic sustainability. These items were added to the questionnaire based on the literature. These items were validated by 8 experts - managers from the hotel industry as well as from psychologists. A five-point Likert scale was used for this measure. A high score on this scale indicated full participation in the sustainable practice by the hotel, while a low score would suggest no participation in that practice.

Motive Attribution: items were adopted from Su-Yol Lee \& Yong Won Seo (2017).

Further, the questionnaire was translated in Hindi and then back into English by a comprehensive language service provider to establish transliteral equivalence. Table 1 summarises the details of the tools used for this research.

Table 1: Details of measures used in this research

\begin{tabular}{llll}
\hline Variables & Components & Author & Scale \\
\hline $\begin{array}{l}\text { Organizational } \\
\text { Identification }\end{array}$ & $\begin{array}{l}\text { Self- categorization } \\
\text { Variables affecting self-categorisation } \\
\text { Emotional attachment }\end{array}$ & $\begin{array}{l}\text { Fred Mael \& Blake } \\
\text { Ashforth }\end{array}$ & Likert scale \\
\hline $\begin{array}{l}\text { Turnover } \\
\text { Intention }\end{array}$ & Intent to leave & G. Roodt & \\
& Job satisfaction & & \\
\hline $\begin{array}{l}\text { Perceived } \\
\text { Sustainability } \\
\text { Practices }\end{array}$ & Perceived environmental & Sivika Saenyanupap & Likert scale \\
& sustainability & & \\
& Perceived social sustainability & & \\
& Perceived economic sustainability & & \\
\hline Motive & Internal Motive Attribution & Su-Yol Lee \& Yong & Likert scale \\
Attribution & External Motive Attribution & Won Seo & \\
& & & \\
\hline
\end{tabular}

In order to contextualise the available questionnaire to the Indian context and check the reliability, the questions adopted from different available questionnaires and questions prepared by the researchers were put for factorization by using the factor analysis. The detailed results of the factor analysis have been presented in the section below.

\subsection{Data Analysis}

The variables in this study were sustainable practices of the hotel, motive attribution for conducting sustainable practices and human resource outcomes which included the turnover intention and organizational identification. The scales were adopted from western studies which made it necessary to see how the Indian sample understands the variable under study. The factor analysis was conducted over 52 items grouped into 4 categories. Further, linear regression analysis was used to understand the effects of perceived sustainability practices and motive attribution on human resource outcomes. The data was entered, coded and analysed using the Statistical Package for Social Science (SPSS).

\section{Results and Discussion}

\subsection{Factor Analysis}

Six items related to organizational identification, six items of turnover intention, 32 items of perceived sustainability practices and 8 items of motive attribution were factor analysed using the Principal Component Analysis (PCA) with Varimax rotation. 
Table 2: Psychometric Properties of Final Factors resulting from Principal Component Analysis

\begin{tabular}{|c|c|c|c|c|c|c|c|}
\hline Variable & Original Dimensions & Dimension & Mean & SD & $\begin{array}{l}\text { Range of } \\
\text { scores }\end{array}$ & $\begin{array}{l}\text { Eigen } \\
\text { Values }\end{array}$ & $\begin{array}{l}\text { Reliability } \\
\text { (chronbach } \alpha \text { ) }\end{array}$ \\
\hline \multirow{3}{*}{$\begin{array}{l}\text { Organisational } \\
\text { Identification }\end{array}$} & Self- categorisation & & & & & & \multirow{3}{*}{0.83} \\
\hline & $\begin{array}{l}\text { Factors affecting self- } \\
\text { categorisation }\end{array}$ & Org. identification & 26.03 & 4.78 & $6-30$ & 3.32 & \\
\hline & Emotional attachment & & & & & & \\
\hline \multirow{2}{*}{ Turnover Intention } & Intent to leave & Intent to leave & 8.44 & 3.14 & 4- 20 & 2.05 & 0.66 \\
\hline & Satisfaction with current work & Satisfaction with current work & 4.39 & 2.11 & $2-10$ & 1.24 & 0.34 \\
\hline \multirow{8}{*}{$\begin{array}{l}\text { Perceived Sustainability } \\
\text { Practices }\end{array}$} & \multirow[t]{2}{*}{$\begin{array}{l}\text { Perceived environmental } \\
\text { sustainability }\end{array}$} & Perceived Organization efforts & 20.20 & 5.15 & 5- 25 & 5.45 & 0.81 \\
\hline & & Perceived Employee welfare & 18.12 & 2.83 & 4- 20 & 2.73 & 0.84 \\
\hline & \multirow[t]{2}{*}{ Perceived social sustainability } & $\begin{array}{l}\text { Perceived optimal resource } \\
\text { utilisation }\end{array}$ & 12.77 & 2.77 & 3- 15 & 2.09 & 0.72 \\
\hline & & Perceived Recycling activities & 6.65 & 3.27 & $2-10$ & 1.83 & 0.84 \\
\hline & \multirow{4}{*}{ Perceived economic sustainability } & $\begin{array}{l}\text { Perceived Sustainable } \\
\text { infrastructure }\end{array}$ & 16.64 & 3.75 & 4- 20 & & \multirow[t]{2}{*}{0.71} \\
\hline & & & & & & 1.39 & \\
\hline & & Perceived Waste reduction & 11.01 & 3.34 & 3- 15 & & 0.58 \\
\hline & & & & & & 1.03 & \\
\hline \multirow{2}{*}{$\begin{array}{l}\text { Motive } \\
\text { Attribution }\end{array}$} & External motive attribution & External motive attribution & 19.12 & 4.84 & 5- 25 & 3.63 & 0.79 \\
\hline & Internal motive attribution & Internal motive attribution & 12.88 & 2.79 & 3- 15 & 1.33 & 0.78 \\
\hline
\end{tabular}

Organizational Identification: The principal component analysis yielded organizational identification as one component explaining a total of $(55.39 \%)$ of the total variance.

Turnover Intention: The factor analysis extracted two components of turnover intention which explains a total of $(54.95 \%)$ of the total variance.

Perceived Sustainability Practices: The PCA of the perceived sustainability practices of the hotels indicated that 6 factors were required to explain the underlying structure, in contrast to the original 3 factors (environmental, social and economic sustainability). The factor structure was obtained depending on the nature of the responses given by the respondents. The structure reflects the perception of the hotel managers in the Indian context. The first factor was identified as ecological responsive efforts comprising 5 items which relate to an organization's initiatives towards sustainability. The second factor was labelled as employee welfare consisting of four items relating to practices to ensure the employee well-being. The third factor was labelled as optimal resource utilization which included 3 items describing resource management that best suits sustainability. The fourth factor made up of 3 items was identified as sustainable infrastructure within the hotel to promote sustainability. The fifth factor was identified as recycling activities of the hotels which comprised 2 items. The sixth factor, Waste Management is a 3-item factor which describes a hotel's efforts to reduce the waste production and management of the same. All the factors together explain (69.24\%) of the total variance. A total of 11 items were eliminated as they failed to meet the criteria of having a loading of 0.5 or more.

Motive Attribution: The analysis yielded motive attribution as two components explaining a total of $(62.07 \%)$ of the total variance. The first factor that emerged was labelled as external motive attribution for undertaking sustainability practices by the hotels. This factor comprised 5 items - improvement of the firm's reputation and image, improvement of customer awareness, cost reduction, reduction in potential danger and will of the CEO. The second factor was labelled as internal motive attribution comprising three items - voluntary responsibility and contribution, preserving resources and operating in a way that is beneficial to the future generations and improvement of the values of the stakeholders. 


\subsection{Effects of sustainability practices and motive attribution on human resource outcomes}

A multiple linear regression was undertaken to examine variance in organizational identification, intent to leave and job satisfaction.

Table 3: Perceived sustainability practices as predictors of organizational identification, intent to leave and job satisfaction

\begin{tabular}{|l|l|l|l|l|l|l|}
\hline $\begin{array}{l}\text { Original MKTOR scale } \\
\text { (15-items, three-factor model) }\end{array}$ & CR & AVE & MSV & CustOr & CompOr & IFC \\
\hline CustOr & 0.957 & 0.790 & 0.810 & $\mathbf{0 . 8 8 9}$ & & \\
$\begin{array}{l}\text { CompOr } \\
\text { IFC }\end{array}$ & 0.902 & 0.698 & 0.810 & $0.900^{\star \star \star}$ & $\mathbf{0 . 8 3 6}$ & \\
\hline $\begin{array}{l}\text { Refined MKTOR scale (11-items, } \\
\text { three-factor model) }\end{array}$ & 0.930 & 0.727 & 0.737 & $0.829^{\star \star \star}$ & $0.859^{\star \star \star}$ & $\mathbf{0 . 8 5 3}$ \\
\hline $\begin{array}{l}\text { CustOr } \\
\text { CompOr }\end{array}$ & $\mathbf{C R}$ & AVE & MSV & CustOr & CompOr & IFC \\
IFC & 0.920 & 0.741 & 0.552 & $\mathbf{0 . 8 6 1}$ & & \\
\hline
\end{tabular}

**Significant at 0.01 level; * Significant at 0.05 level

A multiple linear regression analysis was carried out to examine the effect of perceived sustainability practices and motive attribution to the variance in organizational identification, intent to leave and job satisfaction. The overall F-value predicts all the dependent variables. The results of regression indicate that three dimensions out of eight explain $22 \%$ of the variance in organizational identification, whereas two dimensions explain $6 \%$ of the variance in the intent to leave. Three variables out of eight explain $16 \%$ of the variance in job satisfaction. Table 2 shows that perceived employee welfare, perceived sustainable infrastructure and internal motive attribution significantly predict organizational identification. The perceived employee welfare and external motive attribution negatively and significantly predict the intention to leave. Job satisfaction was significantly predicted by perceived employee welfare and internal motive attribution, as well as by perceived optimal resource utilization. Perceived employee welfare consistently predicts all three outcome variables.

\section{Discussion}

The aim of the study was to understand the moderating effects of motive attribution for conducting sustainable practices in hotels on employees' turnover intention and organizational identification.

\subsection{Effect of sustainable practices on organizational identification of employees}

The results indicate that there is a significant effect of perceived employee welfare and sustainable infrastructure on an employee's identification with the hotel. This finding is congruent to the findings of Dai and Qin (2016) who specified that employees' belief that their organization is making efforts to provide tangible and non-tangible amenities enhances organizational support and motivates him/her to be fully engaged in attaining the organization's goals. Most notably, investing in employees obligates them to return the favours to the organizations in terms of identification and organizational citizenship behaviour (Newman, Miao, Hofman \& Zhu, 2015). Such investments can include efforts to make life worth living for and provide an environment worth working in.

\subsection{Effect of sustainable practices on the turnover intention}

The results show that there is a significant negative effect of employee welfare on the intent to leave. It must be noted that the work in hotel industries require working in a high-pressure environment accompanied with high demands on psychological, emotional and mental resources of the employees. Such over-demanding work exhausts energy, makes one resentful, reduces motivation and productivity leading to burnout and increased turnover intentions. Thus, organizations are required to maximise their efforts towards their employees to retain them. These findings are in line with the conclusions from Tett \& Meyer's study (1993) that was conducted on 112 managers employed in a large organisation on the West Coast of the United States. Hussain\& Asif (2012), in their study on telecom employees of Pakistan, have shown that an organization's employee welfare efforts are a strong predictor of the turnover intention. Bagri, Babu, and 
Kukreti (2011) have suggested in their study that employee welfare and development is necessary to reduce turnover intentions among hotel employees of Kumoan region in India.

The results also indicate that there is a significant effect of employee welfare activities on job satisfaction. The results reveal that if employees perceive that their employers do not provide amenities or facilities to improve their quality of work/ personal life, it will lower their job satisfaction. Practices like corporate social responsibility and sustainability, which are self-regulatory business practices, help to ensure companies take accountability for their actions. These practices are directed towards the employees and have a positive effect on the identification, satisfaction and goodwill mediated via internal respect, that is, respect from the employees (Hameed, Riaz, Arain, \& Farooq, 2016).

\subsection{Effect of motive attribution on organizational identification of employees}

The findings showed that there is a significant positive effect of internal motive attribution on organizational identification. Thus, the hypothesis is proven. These results indicate that attributing pure motives for undertaking sustainability practices predicts employees' identification with the hotel. The organizations must communicate their agenda for conducting these practices and foster participation in sustainability, to improve the identification of employees.

\subsection{Effect of motive attribution on turnover intention}

The results indicate that external motive attribution negatively impacts the intent to leave, while internal motivation affects the job satisfaction. Thus, the hypothesis is proven. Su-Yol Lee and Yong Won Seo's (2017) study reports that when employees perceive that certain activities of the organization do not lead to positive outcomes (like financial benefits and enhanced brand image) from the customers, they believe it poses threat to the organization's performance and in turn creates job insecurity for them.

Further, a poor attribution to pure motives for undertaking sustainability practices will reduce the job satisfaction of the hotel employees. Engaging in sustainable practices means going beyond the organization to do something for the environment, society, and at the same time remain economically viable. Such practices become a criterion to evaluate the management's ethics by both the external and internal stakeholders. Hotels may engage in sustainability because the management is committed to the sustainability agenda or complying to the legislation to avoid risk and punishment. Mere legal compliance is not effective in yielding positive effects of sustainability. Hotels need to 'go beyond mere compliance' to enhance their brand image and satisfy their stakeholders (Kleindienst, Nüskel, Raul \& Schmied, 2017).

Apart from judging the activities of the organisation, the social-economic situation of the country also affects the way employees attribute motives. In developed countries such as North America and Europe, the population live a stable life leaving them enough time to engage and invest in sustainable activities. However, a developing country such as India is constantly dealing with scarcity of resources, unequal distribution of resources, social inequality and corruption (Couret, n.d, Adhikari, 2018). The organisation's inability to boost its own performance and provide means to fulfil the employees' survival needs discourages individuals from perceiving the organisations in the positive light. The high competition among the hotels under study and low pay scale are perceived as a threat to the social and economic well-being and affect their intention to leave.

In sum, the perceived sustainability practices of employee welfare, sustainability infrastructure and optimal resource utilisation predict the organizational identification and turnover intention. Also, the motive attribution by employees was found to have an impact on organizational identification and turnover intention.

The major findings of this research report a significant effect of perceived employee welfare and sustainable infrastructure on hotel employees' organisational identification. The perceived employee welfare has been found to have a significant negative effect on the intention to leave. Employees' attribution of motives for sustainable practices also impact the organizational identification and intention to leave by employees. Specifically, external motive attribution has been found to negatively impact the intent to leave; while the results report positive effect of internal motive attribution on organizational identification of hotel employees. 
Conclusion

In conclusion, the study has contributed to exploring the predictors of organisational identification and turnover intention. Employee welfare activities predict organizational identification and turnover intentions of managers in the hotel industries. Hotel industries must channelise their resources to enhance employee welfare. Utmost care and support will be reciprocated in terms of higher organizational identification and lower turnover rates. Furthermore, intrinsic, as well as extrinsic motive attribution is necessary to encourage employees to take ownership and retain it. The moderating effect of motive attribution should be explored in similar research. The findings of the study suggest that creating awareness in the employees about the reasons for undertaking policies and actions will help them understand the organizational values and encourage them to align their values with the organization. However, sustainability practices and employees' attributions of motives for that alone are not sufficient to discourage employees from quitting or identifying themselves with the organisation. In hotel industries, challenging working conditions and low pay scale are major reasons for high levels of job-hopping. Hertzberg (1959) in his two-factor theory of motivation discussed the role of hygiene factors, the factors that lie outside the nature of the job context and, if lacking, can cause dissatisfaction thereby strengthening the employee's intention to quit. In order to maximise the effect of sustainability practices and commitment to such practices, the hotels must first address the hygiene factors.

This research has managerial implications which demonstrates that directing efforts to educate all the employees as regards the reasons for undertaking policies and actions will help them understand the organizational values and encourage them to align their values with the organization.

The researchers see this study as useful since motive attribution has not been studied in India to understand its impact on employee work behaviour. The way employees allocate reasons for conducting sustainability has implications on the decisions and actions of both managers and employees. It also plays a role in motivating them to involve themselves in sustainable activities.

The study has certain limitations. In spite of continued and repeated effort of the researchers, the response rate was $75 \%$ and mostly the managers of star hotels were not accessible. This rendered critical issues like making some scales less reliable. The present research could not address the moderating role of extrinsic/intrinsic motive attribution to perceived sustainability practices in its relationship with organizational identification and turnover intention because of the small sample size.

These limitations have implications for future research that could provide deeper insights in the role of sustainability practices in human resource outcomes in emerging economies. The future research should investigate the role of motive attribution in moderating the relationship of sustainability practice with turnover intentions and organizational identification. This research also promotes further studies in sustainability motive attribution in different sectors to find out the effectiveness of sustainability policies at the grassroot level. It is also important to study how employees attribute reasons for the organization to undertake different activities like CSR, employee engagement to mark its effectiveness. In addition, studies in sustainability motive attribution in different sectors will elucidate how employees inculcate sustainability in their actions and thus demonstrate the policy success rate.

Employees' perception of sustainability practices as beneficial, socially responsible act of the organization will not only improve employee engagement and performance, but will also result in an overall sustainable growth and development of the wider society.

\section{REFERENCES}

[1] Abbasi, S.M.; Kenneth, H. W (2000) Turnover: The real Bottom Line. Public Personnel Management. Retrieved from https://www.questia.com

[2] Adhikari, Olga (August 2018). Sustainable Development and its Challenges in Developing Countries. International Young Nature friends. Retrieved from http://www.iynf.org

[3] Ameer, R. \& Othman, R. J (2012). Sustainability practices and corporate financial performance: a study based on the top global corporation. Journal of Business Ethics, 108 (1), 61-79. DOI: 10.1007/s10551-011-1063-y

[4] Aselage, J. \& Eisenberger, R. (2003). Perceived organisational support and psychological contracts: a theoretical integration. Journal of Organisational Behavior, 24, 491-509 DOI: 10.1002/job.211

[5] Ashforth, B. E., \& Mael, F. (1989). Social identity theory and the organization. Academy of management review, 14(1), 20-39.

[6] Ashforth, B. E., \& Mael, F. (1992). Alumni and Their Alma Mater: A Partial Test of the Reformulated Model of Organizational Identification. Journal of Organizational Behavior, 13(2), 103 - 123.

[7] Azapagic, A., \& Perdan, S. (2000). Indicators of sustainable development for industry: A general framework. Process Safety and Environmental Protection, 78(4), 243-261.

DOI: 10.1205/095758200530763 Safety and Environmental Protection, 78(4), 243-261.

DOI: $10.1205 / 095758200530763$

[8] Bagri, S.C.,Babu, S. \& Kukreti, M. (2011). Human Capital Decisions and Employee Satisfaction at Selected Hotels in India. Hospitality Review, 29 (1), 104-120.

[9] Blau, P.M. (1964). Exchange and Power in Social Life. New Brunswick, New Jersey: Transaction Publications. 
[10] Carmeli, A. (2005). Perceived external prestige, affective commitment, and citizenship behaviours. Organization Studies, 26, 443-464.

[11] Carmeli, A., \& Freund, A. (2002). The relationship between work and workplace attitudes and perceived external prestige. Corporate Reputation Review, 5, 51-68.

[12] Carmeli, A., Gilat, G. and Waldman, D. A. (2007), The Role of Perceived Organizational Performance in Organizational Identification, Adjustment and Job Performance. Journal of Management Studies, 44, 972 992. DOI:10.1111/j.1467-6486.2007.00691.

[13] Cheney, G. (1983). On the various changing meanings of organization membership: A field study of organizational identification. Communication Monographs, 50, 342-362.

[14] Choi,Y and Yu,Y(2014)The Influence of Perceived Corporate Sustainability Practices on Employees and Organizational Performance. Sustainability , 6(1), 348-364; DOI: 10.3390/su6010348

[15] Couret, Dania Gonzalez (n.d). Sustainability in Developing and Developed Countries. Retrieved from http://www.bvsde.ops-oms.org/arquitectura/anexos/anex01.1.pdf

[16] Dai, K. \& Qin, X. (2016). Perceived Organizational Support and Employee Engagement: Based on the Research of Organizational Identification and Organizational Justice. Open Journal of Social Sciences, 4 , 46-57. Retrieved from http://www.scirp.org/journal/jss/

[17] Dembo, A.M. (2017). The impact of sustainability practices on the financial performance: evidence listed oil and gas companies in Nigeria. Dimensional Corporate Governance, 215-233. DOI: 10.1007/978-3-31956182-0_14

[18] Dutton, J.E., Duckerich, J.M., and Harquail, C.V. (1994). Organizational images and member identification. Administrative Science Quarterly, 39 (2), 239-263.

[19] Essays, UK. (November 2013). The Concept of Sustainability in the Hotel Industry Tourism Essay. Retrieved from https://www.ukessays.

[20] Froese, T. (2013). Employees, Sustainability, Motivation: Increasing employee engagement by addressing sustainability and corporate social responsibility. South Westphalia University of Applied Sciences, Germany.

[21] Giffen, Ryan (2015). Organisational culture and personality type: relationship with person -organisation fit (Doctoral dissertation, lowa State University). Retrieved from https://lib.dr.iastate.edu/etd

[22] Goldstein, K., Primlani, R.V. (2012). Current Trends and Opportunities in Hotel Sustainability. HVS, 2-8. Retrieved from https://www.hvs.com

[23] Hameed, I.; Riaz, Z; Arain, G. A. \& Farooq, O. (2016). How Do Internal and External CSR Affect Employees' Organizational Identification? A Perspective from the Group Engagement Model. Frontiers in Psychology, 7, 788.

[24] Hussain, T. \& Asif. S. (2012). Is Employees' Turnover Intention driven by Organizational Commitment and Perceived Organizational Support? Journal of Quality and Technology Management, VIII (II), 01-10

[25] Kleindienst, D., Nüske, N., Raul, D., \&Schmied, F. (2007). Beyond Mere Compliance-Delighting Customers by Implementing Data Privacy Measures? Proceedings of $13^{\text {th }} /$ nternationale TagungWirtschaftinformatik. Retrieved from www.fim-rc.de

[26] Lee S-Y \&Seo YW (2017). Corporate Social Responsibility Motive Attribution by Service Employees in the Parcel Logistics Industry as a Moderator between CSR Perception and Organizational Effectiveness. Sustainability. 9(3), 355. Retrieved from DOI: 10.3390/su9030355

[27] McMurray, A.J., Pirola-Merlo A., Sarros, J.C. Islam, M.M. (2010). Leadership, climate, psychological capital, commitment, and well-being in a non-profit organization, Leadership \& Organization Development Journal, 31(5), 436-457. Mohsin, A.; Lengler, J.F.B. \& Aguzzoli, R.L. (2015). Staff turnover in hotels : exploring the quadratic and linear relationships. Tourism management., 51, 35-48.

[28] Mohsin,A. Lengler,J.F.B.; \& Kumar,B.(2013)Exploring the antecedents of intentions to leave the job: The case of luxury hotel staff.International Journal of Hospitality Management, 35, 48-58,ISSN 02784319,DOI:10.1016/j.ijhm.2013.05.002.

[29] Mukherjee, A., Malhotra, N. (2004) The relative influence of organisational commitment and job satisfaction on service quality of customer contact employees in banking call centres. Journal of Services Marketing, 18 (3), 162-174, DOI:10.1108/08876040410536477

[30] Newman, A., Maio, Q., Hofman, P.S. \& Zhu, C.J. (2015).) The impact of socially responsible human resource management on employees' organizational citizenship behaviour: the mediating role of organizational identification, The International Journal of Human Resource Management,27(4), 440455, DOI: 10.1080/09585192.2015.1042895

[31] Park, T.Y. \& Shaw, J.D. (2013). Turnover Rates and Organizational Performance: A Meta-Analysis. Journal of Applied Psychology, 98(2), 268-309.

[32] Permarupan, P.Y, Saufi, R.A., Kasim, R., Balakrishnan, B., (2013) The impact of organisational climate on employee's work passion and organisational commitment.Procedia - Social and Behavioral Sciences, 107, 88-95.

[33] Ravikumar, R. "Hotel industry grapples with high attrition, rising staff cost". The Hindu Business Line. 22 April 2011.Web. 23 May 2017. 
[34] Riketta M (2005) Organizational identification: A meta-analysis. Journal of Vocational Behavior,66(2), 358384.

[35] Saenyanupap, S. (2005). Hotel manager attitudes toward environmental sustainability practices: empirical findings from hotels in Phuket, Thailand (Master's Thesis, University of Central Florida). Retrieved from http://etd.fcla.edu/CF/CFE0003710/Saenyanupap_Sivika_201105_MS.pdf

[36] Steel, R.P. \& Ovalle, N.K. (1984, November). A review and meta-analysis of research on the relationship between behavioural intentions and employee turnover. Journal of Applied Psychology, 69(4), 673-686.

[37] Story, J. \&Neves, P. (2015, April) When Corporate Social Responsibility (CSR) Increases Performance: Exploring the Role of Intrinsic and Extrinsic CSR Attribution. Business Ethics: A European Review, 24, 111-124. Retrieved from SSRN: https://ssrn.com/abstract=2577036 or DOI:10.1111/beer.12084

[38] Tett R.P. \& Meyer, J.P. (1993). "Job Satisfaction, Organizational Commitment, Turnover Intention, and Turnover: Path Analyses Based on Meta-Analytic Findings". Person Psychology, 46, 259-293

[39] Vlachos, P.A.; Panagopoulos, N.G.; Rapp, A.A. (2013) Feeling good by doing good: Employee CSRinducedattributions, job satisfaction, and the role of charismatic leadership. Journal of Business Ethics, $118,577-588$.

[40] Woods, K. (2009). Relationship between employee turnover rate and customer satisfaction levels for banking centers. Trevecca Nazarene University, ProQuest Dissertations Publishing, 2009. 3366129

[41] World Commission on Environment and Development. (1987). Our common future, 37 Oxford: Oxford University Press.

[42] World Travel \& Tourism Council (2017). Travel and Tourism Economic Impact 2017 India. Retrieved from www.wttc.org

[43] Yang, Jen-Te; Wan, Chin-Sheng ; Fu ,Yi-Jui (2012).Qualitative examination of employee turnover and retention strategies in international tourist hotels in Taiwan, International Journal of Hospitality Management, 31(3), 837-848.

[44] Yee, R.W.Y, Yeung, A.C.L, Cheng, T.C.E (2008). The impact of employee satisfaction on quality and profitability in high-contact service industries. Journal of Operations Management, 26 (5), 651-668.

[45] Zopiatis,A. Constanti,P; Theocharous,A.L.(2014).Job involvement, commitment, satisfaction and turnover: Evidence from hotel employees in Cyprus, Tourism Management, 41, 129- 140, DOI: 10.1016/j.tourman.2013.09.013

Received: 2018-08-17

Revisions requested: 2018-10-19

Revised: 2019-06-08 (3 times)

Accepted: 2019-06-19

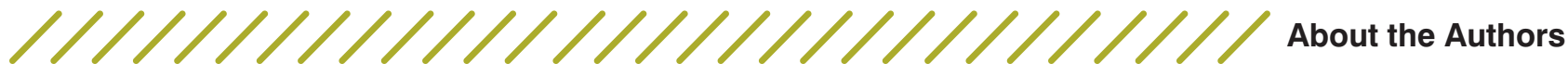

Raesah Tinwala
The Maharaja Sayajirao University of Baroda, Department of Psychology, India raesah.95@gmail.com

Raesah Tinwala is a master's graduate from The Maharaja Sayajirao University of

Baroda. She received a bachelor's degree in psychology, a master's degree in industrial/organisational psychology from The Maharaja Sayajirao University of Baroda, India. She is currently pursuing her career in industrial/ organisational psychology. She is interested in sustainable development, training and development.

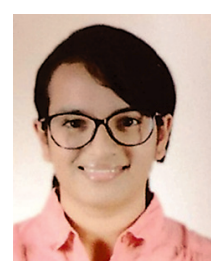

Urmi Nanda Biswas

The Maharaja Sayajirao University of Baroda, Department of Psychology, India biswas.urminanada-psy@msubaroda.ac.in

Dr. Urmi Nanda Biswas is a Professor at the Department of Psychology, The M. S. University of Baroda, Gujarat (India). Her research interests in the field of Organizational

Behaviour include attractive work, employee retention strategies and workforce participation across sectors and national culture. She has published over 50 research articles in peer reviewed journals and book chapters. Recently she has authored a book

titled "Understanding Attractive Work in a Globalised World: Studies from India and Sweden" published by Springer Nature, Singapore. 